\title{
Jurassic and Cretaceous gastropods from hydrocarbon seeps in forearc basin and accretionary prism settings, California
}

Steffen Kiel, Kathleen A. Campbell, William P. Elder, and Crispin T.S. Little

Acta Palaeontologica Polonica 53 (4), 2008: 679-703 doi:http://dx.doi.org/10.4202/app.2008.0412

Fourteen gastropod species from 16 Mesozoic hydrocarbon seep carbonate deposits of the Great Valley Group and Franciscan Complex in California are described. Two genera are new: Bathypurpurinopsis has a fusiform shell with a siphonal fold, and variable Paskentana has turbiniform or littoriniform shells with spiral and/or scaly sculpture and convex or shouldered whorls. Due to the lack of data on shell microstructure and protoconch morphology, many of our taxonomic assignments have to remain tentative at present. Species that are described as new include: Hokkaidoconcha bilirata, $H$. morenoensis, H. tehamaensis (Hokkaidoconchidae), Abyssochrysos? giganteum (Abyssochrysidae?), Paskentana globosa, P. berryessaensis, and Bathypurpurinopsis stantoni (Abyssochrysoidea, family uncertain). The total fauna represents a mixed bag of taxa that were: (i) widely distributed during the late Mesozoic (Amberleya); (ii) restricted to late Mesozoic seep carbonates in California (Atresius, Bathypurpurinopsis, Paskentana); and (iii) members of seep/deep-sea groups with a long stratigraphic range (abyssochrysids, hokkaidoconchids).

Key words: Gastropoda, hydrocarbon seeps, deep-water, Great Valley Group, Franciscan Complex, California.

Steffen Kiel [steffen.kiel@gmx.de], Institut für Geowissenschaften, Christian-Albrechts-Universität Kiel, Ludewig-Meyn-Str. 10, 24118 Kiel, Germany, and Department of Paleobiology, Smithsonian Museum of Natural History, Washington, DC 20013-7012, USA.; Kathleen A.

Campbell [ka.campbell@auckland.ac.nz], Geology Programme, School of Geography, Geology and Environmental Science, University of Auckland, Private Bag 92019, Auckland 1142, New Zealand, and California Academy of Sciences, Invertebrate Zoology \& Geology, Golden Gate Park, San Francisco, California 94118-9961, USA; William P. Elder [chronovision@comcast.net ]: California Academy of Sciences, Invertebrate Zoology \& Geology, Golden Gate Park, San Francisco, California 94118-9961, USA; Crispin T.S. Little [c.little@earth.leeds.ac.uk], Earth Sciences, School of Earth and Environment, University of Leeds, Leeds LS2 9JT, United Kingdom. 
This is an open-access article distributed under the terms of the Creative Commons

Attribution License (for details please see creativecommons.org), which permits unrestricted use, distribution, and reproduction in any medium, provided the original author and source are credited.

Farf Full text $(1,259.8 \mathrm{kB})$ 